\title{
COMPARTIMENTUL
}

ȘTIINT⿱E POLITICE

CZU 551.583:327

DOI 10.5281/zenodo.3980403

\section{THE EUROPEAN UNION AS A LEADER IN INTERNATIONAL CLIMATE CHANGE POLITICS}

\author{
Victoria BEVZIUC \\ Doctor în științe politice, lector universitar \\ Universitatea de stat din Moldova, Facultatea Relații Internaționale, Științe Politice și Administrative, \\ Republica Moldova \\ e-mail: victoriabevziuc@yahoo.ro \\ https://orcid.org/0000-0001-9189-641X
}

The phenomenon of climate change is very complex one. Climate change and problems of its causes and effects are being reserched and analyzed by many researchers, scholars, authors and by representatives of other sciences. A number of books and articles have been written on the climate change process. This is determined by the specificity of the researched problem, which is requiring to analyze it through an interdisciplinary approach, more specific through geopolitical perspective. Since the late 1990s, the European Union (EU) has racked up a series of apparently impressive climate policy achievements which lend substance to the oft-heard claim that it is a global leader in the field. In this context, novel ways to share the efforts required to reduce emissions between its Member States and across different economic sectors have been developed.

Keywords: climate change, programs, emissions, climate policies, global leader, global warming.

\section{UNIUNEA EUROPEANĂ ÎN CALITATE DE LIDER A POLITICII INTERNAȚIONALE A SCHIMBĂRILOR CLIMATICE}

Fenomenul schimbărilor climatice este unul foarte complex. Schimbările climatice și problemele cauzelor și efectelor sale sunt analizate de mulți cercetători, savanți, autori și de reprezentanți ai altor științe. O serie de cărți și articole au fost scrise despre procesul schimbărilor climatice. Acest lucru este determinat de specificul problemei cercetate, care necesită analizarea acesteia printr-o abordare interdisciplinară, mai specifică din perspectiva geopolitică. Incepând cu sfârșitul anilor '90, Uniunea Europeană (UE) a acumulat o serie de realizări aparent impresionante ale politicii climatice care acordă substanță pretențiilor auzite că ea este un lider global în domeniu. In acest context, au fost dezvoltate noi modalități de a distribui, între statele sale membre și între diferite sectoare economice, eforturile necesare pentru reducerea emisiilor.

Cuvinte-cheie: schimbări climatice, programe, emisii, politici climatice, lider global, încălzire globală. 


\section{L'UNION EUROPÉENNE EN TANT QUE LEADER DE LA POLITIQUE INTERNATIONALE EN MATIÈRE DE CHANGEMENT CLIMATIQUE}

Le phénomène du changement climatique est très complexe. Le changement climatique et les problèmes de ses causes et de ses effets sont étudiés et analysés par de nombreux chercheurs, chercheurs, auteurs et représentants d'autres sciences. Un certain nombre de livres et d'articles ont été écrits sur le processus des changements climatiques. Ceci est déterminé par la spécificité du problème étudié, qui nécessite de l'analyser par une approche interdisciplinaire, plus spécifique à travers une perspective géopolitique. Depuis la fin des années 1990, l' Union Européenne (UE) a accumulé une série de réalisations apparemment impressionnantes en matière de politique climatique, qui confortent l'affirmation souvent entendue qu'elle est un leader mondial dans ce domaine. Dans ce contexte, on a développé de nouvelles façons de partager, entre ses États membres et entre les différents secteurs économiques, les efforts nécessaires pour réduire les émissions.

Mots-clés: changement climatique, programmes, émissions, politiques climatiques, leader mondial, réchauffement climatique.

\section{ЕВРОПЕЙСКИЙ СОЮЗ КАК ЛИДЕР В МЕЖДУНАРОДНОЙ ПОЛИТИКЕ ИЗМЕНЕНИЯ КЛИМАТА}

Феномен изменения климата очень сложен. Изменение климата и проблемы его причин и следствий анализируются многими исследователями, учеными, авторами и представителями других наук. О процессе изменения климата был написан ряд книг и статей. Это определяется спецификой исследуемой проблемы, которая требует ее анализа с помощью междисциплинарного подхода, более специфичного с геополитической точки зрения. Начиная с кониз 1990-х годов, Европейский союз (ЕС) накопил ряд, казалось бы, впечатляюших достижений в области климатической политики, благодаря которым он якобы претендует на роль мирового лидера в данной области. В этом контексте были разработаны новые способы распределения усилий между государствами-членами ЕС и между различными секторами экономики, необходимых для сокращения выбросов.

Ключевые слова: изменение климата, программы, выбросы, климатическая политика, глобальное лидерство, глобальное потепление.

Climate change is an increasing risk factor for ecosystems, human health and geopolitical trends in the world and it affects all regions in the world. When the water heats up, it increases its volume. Global warming is also at the origin of melting ice sheets and glaciers. Taken together, these changes lead to increased levels of seas and oceans and, thus, flooding and erosion of coastal and lowland areas. The abundant flooding can lead to the disappearance of some Islands and regions that are strategic important and present a big source of natural resources and influence geopolitical tendencies through the changing of strategic policies regarding the affected territories, home policy on the spread of natural resources.

The climate change science has a relatively long history. The word climate is derived from the Greek word Klima, which meant "inclination, the supposed slope of the earth toward the pole". The concept of science and technology began in the Greek era. Technology, which came through the legacy of the term "techne," was a major product of Greek era [1, pp.120-355].

The term "climate change" is often used to refer specifically to anthropogenic climate change (also known as global warming). Anthropogenic climate change is caused by human activity, as opposed to changes in climate that may have resulted as part of Earth's natural processe. In this sense, especially in the context of environmental policy, the term climate change has become synonymous with anthropogenic global warming. Within scientific journals, global warming refers to surface temperature increases while climate change includes global warming and everything else that increasing greenhouse gas levels affect [2, art.1]. 
A related term, climatic change, was proposed by the World Meteorological Organization (WMO) in 1966 to encompass all forms of climatic variability on time-scales longer than 10 years. During the 1970s, the term climate change replaced climatic change to focus on anthropogenic causes, as it became clear that human activities had a potential to drastically alter the climate. Climate change was incorporated in the title of the Intergovernmental Panel on Climate Change (IPCC) [3] and the UN Framework Convention on Climate Change (UNFCCC). Climate change is now used as both a technical description of the process, as well as a noun used to describe the problem.

Mike Hulme, Professor of Human Geography in the Department of Geography at the University of Cambridge, in his publication „Climate Change, concept of" claimed that Climate change became a phenomenon caused by complex chains of human actions. As this "new" idea of climate change traveled around the world, it became inscribed with multiple and complex political and cultural meanings. In this sense, the idea of climate change has never fully escaped older cultural readings of climate and its changes which have been retained in many nonWestern cultures [4, p.1].

Goosse H., P.Y.Barriat, W.Lefebvre, M.F.Loutre and V.Zunz, English researchers at Cambrige University, in the book Introduction to climate dynamics and climate modelling, highlighted the idea that scince the beginning of the Earth's existence, our planet is covered with a huge amount of icebergs and tones of glaciers. They added that there are some factors that can control the temperature on Earth:

1. volcanic eruptions;

2. ice sheets;

3. vegetal dynamics (forests, jungles);

4. solar irradiance;

5. global carbon cycle [5, p.110].

Great scientific interest for understanding the essence of climate change is shown in the article of Me- dani P Bhandari „Climate change science: a historical outline". This paper provides a brief overview of the scientific developments regarding climate change, showing how the science evolved slowly, however by the end of the 20th century, it began to predict problems. The purpose of the paper is to provide a knowledge base on climate change science. From her point of view, the impact on global climate became most visible in this era. The innovation of high-tech production of toxic chemicals, emissions into the atmosphere and mass consumption of goods and services were the major characteristics of this era.

However, in the 21 st century, the eco-technic era shows some new scenarios on this trend, where people began to realize the serious consequences of climate change caused by human activities (air pollution, water pollution, deforestation, gas emissions, etc.). At the lowest level, people have been exploring energy sources that will have the least impact on global climate. Investment in renewable energy such as the use of sunlight, wind and water for energy generation are a few examples of this kind [6, p.6].

The scientific work „Climate change and Human Health. Risks and Responses" by A.J.McMichel, professor of the Australian National University, should also be noted. In this study, the researcher, besides the essence and context of the climate change process, analyzed also its actual or likely impacts on health, and how human societies should respond, via both adaptation strategies to lessen impacts and collective action to reduce greenhouse gas emissions [7,p.1]

Rocha M., Krapp M., Guesschow J., Jeffery L., Hore B., Schaefter M. in the report Historical responsibility for climate change- from countries emissions to contribution to temperature increase, clamed that the responsibility of countries measured in terms of their share of historical global emissions remains one of the essential parameters in equity proposals, which attempt to distribute efforts among countries in an equitable manner. This report focuses on the 
historical contribution of countries, but takes it one step further: its general objective lies on estimating countries' contribution directly to the increase of global-mean surface-air temperature, and measuring responsibility not based on cumulative emissions but in terms on their actual estimated contribution to temperature increase. Moreover, this report argues that the relationship between countries' emissions and their contribution to temperature increase is estimated using a revised version of the so-called Policy-maker Model, therefore, Policy-maker model provides an approximation for the relationship between emissions and temperature increase $[8, \mathrm{p} .5]$.

In Romanian document "Terra Mileniului III Noțiuni generale despre schimbarii climatice", is shown climate change as a serious problem, as both the natural and socio-economic systems are sensitive to climate change, and the magnitude and speed predicted for them will have a significant impact, which will threaten the sustainability of these systems. As well as, has been thoroughly invenstigated the change in the global temperature of Earth [9, p.2].

Atmospheric changes are not a new topic on the global agenda - the UN agencies have been addressing them since the 1960s. Growing scientific knowledge on the anthropogenic causes of global warming led to the first World Climate Conference in 1979. In their final declaration the participating scientists asked the governments of the world to foresee and prevent potential man-made changes in the climate that might be adverse to the well-being of humanity (Zillman 2009). The conference was followed by several UN negotiation rounds, leading to establishment of the United Nations Panel on Climate Change (IPCC) in 1988. The IPCC, originally erected under the auspices of the World Meteorological Organization and United Nations Environmental Program, is an intergovernmental panel, whose findings must be approved by the governments before they are released to the public.

It is worth to be mentioned, in the international scientifical and legal literature there is no a single definition of climate change and geopolitics that would suit all participants in international relations, even though attempts have been made constantly. An important factor that hinders the achievement of a unified approach to the definition climate change and geopolitics and, as a consequence, the development of the agreed joint international measeures to combat climate change, is the ectreme politicization of the assessments.

The debate over climate change, both from natural causes and human activity, is not new. Although C.-L. de Montesquieu is undoubtedly the best known Enlightenment thinker on the topic of climatic determinism, others, notably the Abbe Du Bos, David Hume, and Thomas Jefferson, observed that climatic changes exerted a direct influence on individuals and society and that human agency was directly involved in changing the climate. Climate - from the Greek term klima, meaning slope or inclination - was originally thought to depend only on the height of the Sun above the horizon, a function of the latitude. A second tradition, traceable to Aristotle, linked the quality of the air (and thus the climate) to the vapors and exhalations of a country.

The WMO's technical report on climatic change published in 1966 systematically compared the statistical properties of different meteorological time series data. Climatic change was definedas "all forms of climatic inconstancy, regardless of their statistical nature (or physical causes)," although inconstancies over less than a decade in length were to be regarded as climatic variations. Thus climatic change encompassed climate periodicities (regular and irregular), fluctuations, oscillations, vacillations, discontinuities, and trends.

The preconditions for a new understanding of global climate change began to emerge in the 1960s, as evidenced in a joint UNESCO / WMO symposium on changes in climate held in Paris in 1963. First, a 
few scholars such as Hubert Lamb in the United Kingdom and Emmanuel Le Roy Ladurie in France began publishing accounts of historical climate change based on long climatic reconstructions derived from documentary and environmental evidence. Second, new developments in scientific monitoring of theplanet, boosted by theInternational GeophysicalYearin 1957/ 1958andbynewsatellite technologies, prompted a new conception of climate as an interconnected system of atmosphere, ocean, biosphere, and cryosphere.

Third, this idea of a human-induced change in global climate found sympathy in the broader currents of intellectual thought of the 1960s and 1970s. The emergence of a new environmentalism focused attention on the planetary scale effects of human activities on the physical world. And the first governmental and international assessments of the prospects of climate change were conducted during this period. In the United States for example, the President's Scientific Advisory Committee in 1965 published a report on "Restoring the Quality of our Environment," which included a specific section on "the climatic effects of pollution" [10, p.1].

The growing political resonance of climate change was partly explained by the dissolution of the Soviet Union between 1989 and 1991. The evolving scientific definition of climate change can be discerned through successive assessment reports of the IPCC. In its First Assessment Report in 1990, no very precise definition of climate change was offered, although it was stated that the "climate change we are addressing in this report is that which may occur over the next century as a result of human activities" [11, p.20]. A few years later, the Second Assessment Report was more explicit. Climate change meant "climate fluctuations of a global nature and which includes the effects due to human actions and those due to natural causes" $[12$, p.23]. By 2001 the IPCC had settled on a definition which also prevailed for its Fourth and Fifth Assessment Reports: "Climate change refers to statistically significant variation in either the mean state of climate or its variability, persisting for an extended period (typically decades or longer). Climate change may be due to natural internal processes or external forcings, or to persistent anthropogenic changes in the composition of the atmosphere or in land use" [13].

While the IPCC understood climate change to embrace both natural and human causes, for the UNFCCC - signed in 1992 - climate change was to mean "a change of climate which is attributed directly or indirectly to human activity that alters the composition of the atmosphere and which is in addition to natural climate variability observed over comparable time periods" [14, p.3]. The contrasting definitions between these scientific and political usages have resulted in considerable strategic ambiguity in the public meaning of climate change.

Sivakumaran Sivaramanan, an Asian researcher in her article "Global Warming and Climate change causes, impacts and mitigation" explains that global warming and climate change refer to the increase in average global temperatures due to the increase in greenhouse effect by the increase in the greenhouse gases. Natural events such as forest fires, volcanic eruptions, methane release from thawing of permafrost on the ocean floor and release of methane gas from cattle, wet lands and anthropogenic sources of exhausts from all kinds of combustion, industrial production of greenhouse gases, agricultural water lodging activities such as paddy cultivation artificial wet lands and deforestation. Warming of the earth causes rapid changes in pre-existing weather pattern. According to National Oceanic and Atmospheric Administration (NOAA) there are several indicators those changes with the warming world.

Sivakumaran Sivaramanan undelines factors increases with global warming:1) Temperature of land; 2) Sea surface temperature; 3) Troposphere temperature; 4) Temperature over oceans; 5) Ocean heat content; 6) Sea level; 7) Humidity; and factors 
decreases with global warming: 1) Glaciers; 2) Snow cover; 3) Sea ice [15].

Another famous work that elucidates the meaning of climate change is "Historical perspective of climate change" by James Rodger Fleming, thar presents a huge explanation of the sudy of climate change. Here he analyses great works and personalities that had developed and explaned the concept of climate change, such as Abbe Du Bos, Charles Louis de Secondat Baron de Montesquieu, David Hume. Collectively, they generated a powerful vision of the climates of Europe and America shaping the course of empire and the arts; the concerted efforts of innumerable individuals in turn shaping the climate itself. By the end of the eighteenth century, Enlightenment thinkers had come to the following conclusions regarding climate change, culture, and cultivation:

1. Cultures are determined or at least strongly shaped by climate.

2. The climate of Europe had moderated since ancient times.

3. The change was caused by the gradual clearing of the forests and by cultivation.

4. The American climate was undergoing rapid and dramatic changes caused by settlement.

5. The amelioration of the American climate would make it more fit for European-type civilization and less suitable for the primitive native cultures [16].

Contrasting accounts of climate change offer different interpretations of cause, significance, and responsibility, even while anchoring the idea of climate change in the changing weather attributes of the climate system.

The climate crisis could make or break the European Union (EU). The continent urgently needs a comprehensive, transnational policy for a fair transition to a sustainable, low-carbon economy. Such a policy could become a significant driver of deeper European integration. In 2019, the EU has taken a major step forward with the European Green Deal, a comprehensive policy that covers all sectors of the economy. Even during the European Parliament elections back in May, climate was a unifying issue. The Greens gained support, but more significantly, all the other mainstream parties began to make their political platforms more ecofriendly. The wave of support from youth activists gave new momentum to climate action, and the incoming European Commission and European Parliament put the issue at the top of the EU's agenda [17]

However, the political obstacles to effective climate action are formidable and will get bigger as the EU introduces concrete measures. Things could go badly wrong if dysfunctional decisionmaking blocks action and if polarized governments provoke a backlash. What is more, over the next five years, climate politics could go from being relatively benign to downright nasty. Well-funded business interests will mobilize opposition. Populist parties are denying the reality of human-caused climate change, while others are co-opting the ecological crisis to support calls for protectionism and against migration. Resistance to the radical policy measures that are needed could rapidly lead to political paralysis and a political blame game. Meanwhile, frustrated citizens could easily become fearful about who will bear the adjustment costs, especially if the European economy falls into another recession in the next few years.

The EU has to reform its institutions and policies rapidly to handle the toxic politics that will emerge during the climate transition. It is vital to start building public support for climate policies early on in 2020 and 2021. More than 90 percent of Europeans view climate change as a "serious problem" and believe emissions should be curbed to make the EU carbon neutral; many of them are prepared to adjust their lifestyles to achieve that goal [18]. But they do not want an unfair transition that puts most of the costs on households and consumers. Meanwhile, the costs of 
inaction are rising, with the most vulnerable citizens bearing much of the burden of energy inefficiency and extreme weather conditions.

The prospects for effective climate action by the EU are shaped by two contradictory dynamics in European politics. Exposed to the same economic and technological forces, Europeans are ever more connected, with more similar lifestyles and aspirations, but politics is becoming ever more fragmented, volatile, and polarized. The old mainstream parties based on collective class and religious identities are losing ground not only to challengers on the far right and the left but also to new entrepreneurs in the political center. EU politics was long immune to these trends, but now it looks more and more like national politics. In the past, national politics was marked by ideological divisions and party power plays, while EU politics was governed by a permanent grand coalition that represented a broad centrist consensus and favored technocratic decisionmaking.

The problem is that the EU's traditional methods of making decisions are ill-suited to a polarized, unpredictable political environment. The old methods rely on the willingness of politicians to compromise and seek consensus; on lengthy, painstaking negotiations; and on a penchant for turning hot political topics into technocratic issues. The EU's political decisionmaking system is being shaken up just when it needs to take decisive action. In addition to the climate challenge, Europeans are facing other unprecedented challenges that require transnational responses from the digital transformation to aging populations. The EU's capacity to forge common responses and implement coherent policies is crucial for meeting these challenges [19]. But to do so successfully over the next few decades, the union will have to upgrade its ability to manage volatile and polarized politics.

Climate action is a game changer because the whole economic system has to change - and change fast. The EU was able to create the single market and the Schengen area of passport-free travel over many years. But the political pressure to take decisive action to prevent catastrophic loss of habitat and other effects of climate change is already long overdue. Scientists on the Intergovernmental Panel on Climate Change already have warned that humanity has only eleven years to avert catastrophe [20]. The EU cannot take another decade to decide how to sequence measures and how to pay for them.

Climate change obviously requires EU-level measures, but action is hard to agree when exposure to climate-related problems varies across the continent. Its effects will be felt by farmers facing drought, people living in flooded coastal regions, coal miners whose livelihood is disappearing, and many other interest groups across the continent. Reconciling all of these interests will be a huge challenge. Europeans need to see climate measures as part of a common agenda that is coherent and strategic, so that they can trust that today's sacrifices will bring a better future for all, including their children.

Climate change is the ultimate global challenge. The EU has to do its share but also needs to persuade others to take effective action. Brussels has a good track record as an international leader on climate policy, but it will have to do a great deal more. This will require that Europe demonstrate heightened ambition, clearer priority setting, and greater readiness to use its leverage. Foreign policy can no longer be the neglected stepchild of EU integration.

For all these reasons, the many levels of European politics - especially on the national and EU stages need stronger connections that can engender a shared sense of responsibility and reinforce various officials' determination to act. At the same time, the EU must deepen democratic engagement with citizens to mobilize for large-scale, coherent, and binding measures to address climate change.

EU political and policymaking structures need to adapt accordingly. The task before European leaders 
is not just about the specific policy measures needed to mitigate climate change but also how to negotiate them through an EU political system designed for a different political age.

The EU already has a long track record on climate change policy. It has been an influential player in international negotiations on the issue, consistently advocating for ambitious targets and timetables for action. Brussels has set a range of targets for emissions reductions for 2020 and 2030, as well as aspirational targets for 2050. These include a collective EU-wide commitment under the Paris Agreement to reduce annual emissions of greenhouse gases by 40 percent below 1990 levels by 2030. This target will be reviewed in 2020, with the goal of lowering emissions even more, with leaders like European Commission President Ursula von der Leyen aiming for a total reduction of 50 or 55 percent by 2030 [21].

These targets have informed several policies and regulations designed to reduce emissions, increase the uptake of renewable energy, and improve energy efficiency. The EU has established the world's largest carbon market, the EU Emissions Trading System (ETS), which covers 45 percent of the EU's greenhouse gas emissions and 11,000 industrial plants [22]. Other major economies are even replicating this system. Europe considers itself, with justification, to be a global leader on environmental standards ranging from energy efficiency standards for household products (for example, based on the EU's prevailing Ecodesign Directive provisions) to emissions standards for passenger cars. In early 2019, the European Council and the European Parliament agreed on a set of eight legislative acts known as "Clean Energy for All Europeans." This marks a major step in overhauling the EU's existing energy policy with a legislative package covering energy efficiency, targets for renewable energy, and a new governance system for the energy union, among other areas [23].
Several factors have contributed to the limitations of Europe's climate policy. The EU's limited enforcement capacity has opened holes in implementation owing to knowledge gaps and design flaws, such as those detailed above with the ETS. Polices have often not been accompanied by appropriate delivery and monitoring mechanisms. Debates over climate policy have been dominated by concerns over the supposed burden of regulation on businesses, a tendency deepened by industry associations that highlight the risks of climate action to international competitiveness and jobs. Climate policy has been delegated to a handful of directorates general within the European Commission without any central coordination until the recent creation of an executive vice president for climate action.

Ultimately, one of the most intractable difficulties has been contending with the national interests represented in the European Council. Member states continue to have a high degree of autonomy on energy, taxation, and land-use policies, three key areas for climate action. National sensitivities over energy security and fears about competitive advantage have diluted policy ambitions.

Contentious political dynamics will likely be a further drag on the EU's capacity to deliver the transition required. Some national governments have recently shown more assertive opposition to climate action. At the June 2019 European Council meeting, the Czech Republic, Estonia, Hungary, and Poland refused to sign on to a long-term target of achieving climate neutrality by 2050, then Poland still held out alone in December 2019, demanding more detailed guarantees of financial aid from the EU [24]. These countries are seeking compensation for regions and industries immediately affected by the ongoing transition, such as coal mining. If the EU gives in to blocking behavior, such payments to the immediate losers from the transition could rapidly deplete the public funds available for the whole enterprise. The EU will need a grand bargain 
that creates a social safety net for citizens who lose out in the short term, but it must concentrate public investment and compensation primarily on creating economic incentives for decarbonizing production and moving the climate agenda forward.

The EU's Paris Agreement commitments to reduce emissions are not enough to avert catastrophe in time. The EU has to act more urgently and effectively. The technocratic methods of the past will not suffice anymore. Addressing climate change requires accommodating diverse interests in a democratically inclusive way. To gain the necessary political support, Brussels must not depoliticize climate action and make it more technocratic. Given the high stakes and the profound impact on Europe's whole population, any such attempt would result in certain deadlock. There is no alternative to building public support for climate action and to strengthening democratic engagement. Politicians must show that the transition will be fair, or it will not be sustainable politically.

The strong interplay between EU and national politics makes governing even more complex, especially on an issue as technical and contentious as climate action. To deal with this, the EU needs to build deeper connections between various levels of government and facilitate more effective engagement with citizens.

Setting priorities is vital for climate action to work politically, because the sequencing of measures is what enables people to see how they will be affected. But sequencing is made harder with so many actors, parties, and institutions that hold veto power at various points. An example from France is instructive on this point. The country experienced a backlash from badly sequenced measures when the government hiked fuel taxes without compensating by reducing other taxes for rural dwellers and the poor. The result was the gilet jaunes (yellow jackets) movement, whose demonstrators protested about the costs falling on them rather than those who could better afford them. A similar situation could easily arise if the EU ignores the social implications of its reform measures.

To build the strongest possible consensus among voters, other stakeholders, and institutions on a clear set of guiding principles for climate action, the EU needs to adopt binding action plans, including firm timelines for implementing these goals. Specifically, the EU must ensure that the policies it enacts are fair, durable, trusted by the public, positively reinforcing, innovative, and visionary. To that end, Brussels' climate action should:

Promote fairness by making sure that the climate transition is just and serves the broad public interest.

If the climate transition is not clearly fair and if climate measures look set to reinforce existing inequalities, it will not gain public support. The transition must also meet economic and social justice objectives so that the burden does not fall disproportionately on the poor and most vulnerable. Emphasizing fairness is the way to keep the EU countries - poorer and richer regions - together and prevent populists from driving a wedge between citizens. Already new dividing lines are appearing, with some EU member states from Eastern Europe claiming that climate change is a Western European concern. Moreover, disinformation campaigns are already spreading climate denial in the region to try to maintain European dependence on Russian natural gas. But hotter summers and changing rain patterns are already affecting farming in Central Europe, so a key argument is that inaction on climate change will not serve the interests of the people of the region. Explaining the enormous cost of not doing anything is instrumental to winning public support.

A new social contract between European states and their citizens will be needed to ensure that the overall transition is fair, a challenging prospect at a moment when trust in government is low. The EU could help by creating plans that hold governments accountable. 
To maintain accountability and public consent to unpopular climate change measures, further mechanisms will need to be developed to monitor the progress of the EU as a whole toward carbon neutrality, as well as that of specific countries and regions [25]. Developing such mechanisms is vital because that would let people see that climate measures are having a real impact and that governments are committed to action, not only rhetoric.

The EU already has legal and financial instruments that are much more binding than the $\mathrm{UN}$ and relevant international agreements on climate change. It can apply positive and negative conditionality through the EU budget, EU law (and infringement proceedings when governments fail to apply it properly), and naming-and-shaming tools such as the European Semester reports on economic governance. All these instruments will be needed for the climate transition, preferably under an independent monitoring body that is nonpolitical and trusted by the public. The EU needs to close the implementation gap by using these tools and relying less on soft and market-based measures in future.

The European Commission has already proposed the creation of a Just Transition Mechanism (JTM) of some 100 billion euros, in addition to the EU budget [26]. This fund is necessary, but it needs to be guided by two key principles to avoid misallocating resources. First, it must reward contributions to the transition to a greener European economy, not blocking behavior. The quickest way to do that would be for the EU to create a condition that countries that do not sign on to the 2050 goal or other main climate policy objectives will not be eligible for major parts of the funds. As an EU diplomat warned at the December 2019 European Council meeting, "The JTM is not an ATM" [27].

Second, funding should not be spent first on compensating short-term losers from the first climate change measures that are enacted. Otherwise, rent- seeking entrepreneurs could, for example, buy up end-of-life coal-fired power plants expecting to be paid from public funds to close down those plants, including under the Energy Charter Treaty.

If the EU rewarded such behavior, it would create a constituency of lobbyists clambering to gobble up public money as compensation for each and every stage of the economic transition. Doing so would also divert funds from more productive investments designed to create new economic opportunities, and it would destroy social trust by leaving few resources to compensate those affected by later stages in the transition. More fundamentally, a compensationfocused approach would increase public resistance to any policy changes for which citizens are not immediately compensated. Both governments and citizens need to replace the mentality that someone must compensate them for their losses with the idea that they are contributing to the creation of a betterfunctioning economy that serves everyone.

A focus on short-term transactionalism and incrementalism is dangerous because the European Green Deal needs to be an overarching, visionary social contract and a comprehensive plan for the decades ahead. Incrementalism is also dangerous in the European Council, where EU members' heads of state and government meet several times a year. If the EU keeps lurching from one European Council summit to the next with short-term deals that kick the can down the road, as it has for the last decade on the euro, then it will waste time and erode public trust in the European Green Deal. It would also create completely the wrong political culture to achieve a fair transition.

Effective climate action depends on transferring all resources as rapidly as possible from the unsustainable brown economy into the circular green economy to produce new jobs and economic opportunities. The goal is not just to forcibly shut down so-called dirty industries for the sake of shutting them down but to create a set of incentives for market players to shift 
resources into more sustainable industries of their own accord and thus create new, more sustainable forms of economic value.

To bring things back to the point of fairness, the costs of the economic transition cannot place too heavy a burden on citizens who have limited lobbying power and whose losses may come down the road and be hard to calculate, while others whose losses are short-term and visible pay little. There does need to be a social safety net for those who fall into poverty as a result of the transition. But publicly funded compensation should directly spur on the transition to sustainability and create new economic opportunities for those who have lost out, not just give them money. For example, offering reskilling programs and new climate-neutral jobs in regions where carbonintensive jobs are lost would be better than merely paying people off.

Inspire and model policy innovation by encouraging policymakers to be inventive and design policies that can be adopted in other parts of the world.

The EU has a great opportunity to promote policy innovation and experimentation regionally and locally across Europe. There is a need for authorities that can monitor progress effectively and report on policy successes and failures. The task of decentralizing the generation of energy from renewable sources is a notable example. If successful, the EU and its member states can then share their experiences with other parts of the world and exchange best practice on the climate transition. The success of the European Green Deal will be marked not only by reducing carbon emissions in the EU but by helping other countries incorporate cleaner production cycles and sustainable development.

The EU needs to focus on fostering a global climate transition now. EU markets and investment have great potential to foster the global transition to a greener economy. EU trade policy and regulations could start pricing the environmental costs of all parts of production cycles, a step that could kickstart a worldwide change in economic incentives in favor of sustainability. Such a push needs to go beyond just a border carbon adjustment on imports by factoring in all the environmental and human costs in production cycles.

Frans Timmermans' job as the EU's international envoy involves building partnerships with countries that are ready and willing to lead global efforts to transition to carbon neutrality. He will need to work with others - most notably Josep Borrell, the new EU High Representative for Foreign and Security Policy - to help tackle the geopolitical effects of climate change. This is a hard job because the EU's usual ally on matters of international governance - the United States - currently has an administration that denies human-caused climate change. The EU cannot wait until after the next U.S. presidential election in November 2020 to plan how to ratchet up climate action with other willing countries at the next major UN-sponsored climate change conference, which will take place that same month.

There are at least three major advantages of deliberative citizen participation for long-term issues like climate change. First, many more people can be involved in deliberative policy discussions than through traditional methods of public consultation. Second, those discussions are better informed and go deeper into the details than election campaigns tend to. Third, such deliberations help legitimize action on tricky ethical and social issues on which no political party wants to take a position. Deliberative forums allow citizens to discuss and even decide on trade-offs between competing interests and objectives.

The EU should develop a way to use these consultations on all important legislative initiatives. They are especially vital for climate action and sustainability because of the scale, complexity, and lengthy time horizons of these policies. A great start would be for the EU to use public consultations on the European 
Green Deal as a pilot project for enhanced citizen participation. For example, the outcomes of citizens' assemblies on specific climate measures could be the basis of corresponding European Parliament draft resolutions.

Second, the EU should involve national parliaments, regional authorities, and local leaders more systematically in EU policymaking to ensure coherent action on climate change. One idea would be to let national parliaments put forward ideas for legislative initiatives. New European Commission President Ursula von der Leyen has committed to give the European Parliament an indirect right of initiative: if a majority votes for an initiative, she has pledged that the commission will submit a legislative proposal along those lines. A similar mechanism could be developed to allow a quorum of national parliaments to put forward ideas for new legislation on climate action [28].

Another idea would be for members of European Parliament to be given the right to participate in national parliaments' debates on EU matters and commissioners to be tasked with conveying and explaining EU policies in relevant institutions in the member states where they speak the language. For example, they could use their visits to all the member states next year to talk with citizens of the many regions and municipalities throughout the EU. The point is to connect EU-level politics more effectively with the local and regional levels. Local and regional leaders are closer and more familiar to citizens, who trust them more than national and EU institutions.

Mayors in particular have an important role to play on climate action because so many measures need to be implemented in cities - from recycling to the sustainable use of energy and water - and municipalities have vastly different implementation powers. Building on existing initiatives like the EU Covenant of Mayors, further efforts need to be made to engage municipalities on climate action [29]. The climate transition will cause some energy production to be decentralized to the local level because renewable sources of energy (such as solar and wind power) tend to be more local than fossil fuel generation. Even more opportunities for local engagement will come in transport and housing, two major policy areas that need rapid decarbonizing.

Third, the European Parliament's capacity to support climate action should be strengthened. The body plays an important role as the primary forum for holding governments to account for their commitments to the whole EU's transition to a zero-carbon economy. To serve this function, the parliament needs new instruments to monitor progress based on the best available scientific advice.

Given the scale of the challenge, the EU needs a new type of leadership that is more political, more visionary, and more appealing across national borders. Gone are the days when technocrats could do backroom deals out of public view. The leaders of the EU institutions - especially the commission - need to be able to engage with all Europeans, across languages, and beyond national representatives. For such leadership to take hold, the Spitzenkandidat system needs to be reformed. Moreover, the candidates for the top jobs should head the transnational candidate lists for European Parliament, so that they run on a common campaign platform that is thoroughly debated in all the member states.

\section{Conclusions}

If handled badly, the politics of climate change could massively deepen the divisions between EU and national politicians, governments and civil society, rural and urban regions, and various generations and social classes. That could lead to toxic political fights, multiple impasses, and a politically irrelevant EU. Such a corrosive, divisive political environment could deepen existing power inequalities and curtail economic and social justice. Populist politicians are 
already falsely painting climate change as an elite concern rather than a scientifically proven phenomenon that will affect every human being.

The answer is for the EU to commit deeply to its comprehensive plan for climate justice-effective ways to reduce the EU's emissions and an economic transition that is clearly fair. A comment from one of the gilets jaunes protesters in France that went viral earlier this year is noteworthy. It summed up the fears of many Europeans: "[The elites] worry about the end of the world, while we worry about the end of the month" [30]. The EU has to show that it has solutions for both concerns, that the low-carbon, sustainable economy will be more just, and that the costs of adjustment will be spread fairly.

If the EU gets it right, a fair climate transition could advance social and economic justice in ways that market economics has failed to deliver. Climate action could even become a great integrating force for the continent in the coming decades. Europe urgently needs to develop better ways of handling the politics of climate change, both for its own transition and for the sake of becoming an effective leader of global action. The stakes could not be higher for the EU or for the human race.

\section{Bibliography}

1. Chester RL. Origin of the Word Climate. Science in the Science, 27 August 1954, p.120-355.

2. United Nations Framework Convention on Climate Change. - New York, 1992, Article 1.

3. Intergovernmental Panel on Climate Change (IPCC). 1990. Climate Change: The IPCC Scientific Assessment. Cambridge: Cambridge University Press.

4. MIKE, H. Climate Change, concept of. In The International Encyclopedia of Geography, 2016, p.1.

5. GOOSSE, H., BARRIAT, P.Y., LEFEBVRE, W., LOUTRE, M.F. and ZUNZ, V. Introduction to climate dynamics and climate modelling. - Cambrige University, 2010, p. 110.
6. BHANDARI, M.P. Climate change science: a historical outline in Advances in Agriculture and Environmental Science: Open Access. February 2018, p. 6.

7. MCMICHEL, A.J. Climate change and Human Health. Risks and Responses. World Health Organization. - Geneva 2003, p. 1.

8. ROCHA, M., KRAPP, M., GUESSCHOW, J., JEFFERY, L., HORE B., SCHAEFTER, M. Historical responsibility for climate change- from countries emissions to contribution to temperature increase. Climate Analytics and Potsdam Institute for the Climate Impact Research. November 2015, p.5.

9. Terra Mileniul III. Fenomenul Schimbărilor climatice. p.2.

10. Report of The Environmental Pollution Panel President's Science Advisory Committee. The White House, November 1965, p.1.

11. The IPCC Scientific Assessment, 1990, p.20.

12. IPCC Second Assessment Climate Change, 1995, p.23.

13. IPCC Fourth anf Fifth Assesment Report, 2001.

14. United Nations Framework Concept on Climate Change, 1992, p.3.

15. Sivakumaran Sivaramanan. Global Warming and Climate change causes, impacts and mitigation. Central Environmental Authority. September 2015.

16. FLEMING, J.R. Historical perspective of climate change. - Oxford University Press, 1998.

17. LEYEN, von der, U. "Press Remarks by President von der Leyen on the Occasion of the Adoption of the European Green Deal Communication," European Commission, press release, December 10, 2019, https:/ec.europa.eu/com$\mathrm{mission} / \mathrm{presscorner} / \mathrm{detail} / \mathrm{en} / \mathrm{speech}$ _19_6749. (Accesat 24.03.2020).

18. European Commission, "Citizen Support for Climate Action: 2019 Survey," 2019, https://ec.europa.eu/ clima/citizens/support en.(Accesat 24.03.2020).

19. GRABBE, H., VALÁЉEK, T. (Eds.) Refocus the European Union: Planet, Lifetime, Technology (Washington, DC: Carnegie Endowment for International Peace, 2019), https://carnegieeurope.eu/2019/04/30/ refocus-european-union-planet-lifetime-technology-pub79008. (Accesat 25.03.2020). 
20.MASSON-DELMOTTE, V., ZHAI, P. M., PÖRTNER, H.-O., ROBERTS, D.C., SKEA, J. et al., Global Warming of $1.5{ }^{\circ} \mathrm{C}$ (Geneva, Switzerland: Intergovernmental Panel on Climate Change, 2018), https:// www.ipcc.ch/sr15/. (Accesat 25.03.2020).

21. SCHAART, E. "Von der Leyen Pledges Higher Climate Targets Ahead of Key Vote," Politico Europe, July 16, 2019, https://www.politico.eu/article/von-derleyen-pledges-higher-climate-targets-ahead-of-key-vote/. (Accesat 31.03.2020).

22."The EU Emissions Trading System (EU ETS)," European Network of Regional GhG Emissions and Energy Watch, https://energee-watch.eu/international-carbonmarket/.( Accesat 31.03.2020).

23. European Commission, "Clean Energy for All Europeans Package Completed: Good for Consumers, Good to Growth and Jobs, and Good for the Planet," May 22, 2019, https://ec.europa.eu/info/news/clean-energyall-europeans-package-completed-good-consumers-goodgrowth-and-jobs-and-good-planet-2019-may-22_en. (Accesat 25.03.2020).

24. "From 30 Eurocents to 25 Euros: The Price of a Tonne of CO2," Fair Climate Fund, May 16, 2019, https:// www.fairclimatefund.nl/en/news/from-30-eurocents-to-25 -euros-the-price-of-a-tonne-of-co

25. KHAN, M. "Poland Resists EU Carbon-Neutral Ambition," Financial Times, December 12, 2019, https:// www.ft.com/content/560feece-1 d06-11 ea-97dfcc63de1 d73f4?emailId $=5$ df2367 cda2e3c000470a6f2 \& segment $\mathrm{Id}=488 \mathrm{e} 9 \mathrm{a} 50-190 \mathrm{e}-700 \mathrm{c}-\mathrm{cc} 1 \mathrm{c}-6 \mathrm{a} 339 \mathrm{da} 99 \mathrm{cab}$. (Accesat 24.03.2020).
26. European Commission, "Emissions Monitoring and Reporting," https://ec.europa.eu/clima/policies/strategies/ progress/monitoring_en. (Accesat 31.03.2020).

27. European Commission, "The European Green Deal Sets Out How to Make Europe the First Climate-Neutral Continent by 2050, Boosting the Economy, Improving People's Health and Quality of Life, Caring for Nature, and Leaving No One Behind," press release, December 10, 2019, https://ec.europa.eu/commission/presscorner/detail/ en/ip_19_6691; and "EU Leaders Haggle Over Climate Neutrality Pledge," BBC, December 12, 2019, https:// www.bbc.com/news/world-europe-50744784. (Accesat 24.03.2020)

28. KHAN, M. "Climate Contortions at EU Leaders' Summit," Financial Times Brussels Briefing (email newsletter), December 13, 2019, https://www.ft.com/ content/0b4683ba-1d71-11ea-9186-7348c2f183af. (Accesat 06.04.2020).

29. Energy Cities, "Covenant of Mayors for Climate and Energy," https://energycities.eu/project/covenant-ofmayors-for-climate-energy/

30. MCNICOLL, T. " End of the World' Vs. 'End of the Month,': Macron Walks Tightrope Amid Fuel Tax Protests," France 24, November 27, 2018, https://www.france24.com/ en/20181127-france-climate-yellow-vests-macron-fuel-taxprotests-nuclear-melenchon-pen-faure; and Pauline Bock, "France's Violent 'Yellow Vest' Protests Are About Much More Than a Fuel Tax. But Is President Macron Listening?" NBC News, December 8, 2018,https://www.nbcnews.com/ think/opinion/france-s-violent-yellow-vest-protests-areabout-much-more-ncna945481. (Accesat 06.04.2020). 